\title{
From Disparity to Harmonisation of Construction Industry Payment Legislation in Australia: a Proposal for a Dual Process of Adjudication based upon Size of Progress Payment Claim
}

Jeremy Coggins (School of the Natural \& Built Environments, University of South Australia; PhD candidate, University of Adelaide, Australia)

\begin{abstract}
Since the introduction of the Building and Construction Industry Security of Payment Act into New South Wales in 1999, construction industry payment legislation has progressively been enacted on a jurisdiction-by-jurisdiction basis throughout Australia. Of the eight Australian Acts, two distinct legislative models can be discerned - what have been termed the 'East Coast' and 'West Coast' models. This article compares the two models with respect to their payment systems and adjudication schemes, procedural justice afforded, incursion upon freedom of contract, uptake rates and efficiency. From this comparison, the strengths and weaknesses of the two models are identified. Finally, a dual process of adjudication based on progress payment claim size is proposed for a harmonised model, developed from previous proposals put forward by other authors, which aims to combine the strengths of the two existing models.
\end{abstract}

\section{Introduction}

Over the past 13 years, construction industry payment legislation ('the legislation') has come into force in several Commonwealth jurisdictions. A common objective of all of this legislation has been the eradication of unfair contractual provisions and practices with regards to payment in order to get cash flowing in as fair a manner as possible down the hierarchical contractual chains that exist on most commercial construction projects. A central feature of all this legislation is the provision for a rapid statutory adjudication scheme, designed to facilitate quick and inexpensive resolution of contractual payment disputes in the construction industry. There is general consensus that the legislation has had a significant and positive effect on the construction industry in those jurisdictions where it has been enacted.

In Australia, the first jurisdiction to pass such legislation was New South Wales (NSW). The NSW Act formed the model upon which most other Australian jurisdictions, to varying degrees, progressively based their legislation culminating in the Tasmanian Act which received Royal Assent on 17 December 2009. A list of the relevant Acts is presented in Table 1. The consequence of this piecemeal, jurisdiction-by-jurisdiction, approach to enacting the legislation throughout Australia has been inconsistency, to varying degrees, between the various Acts. Such inconsistency is particularly marked, with respect to the underlying conceptual frameworks and detail of the drafting, between the Western Australia (WA) and Northern Territory (NT) Acts on the one hand which more closely resemble the construction industry payment legislation in the United Kingdom (UK) and New Zealand (NZ), and the other Australian Acts on the other which are more closely modelled on the NSW Act.

Accordingly, the WA and NT Acts have been collectively labelled (Stenning \& Associates 2006) as the 'West Coast' model legislation as opposed to the 'East Coast' model tag given to the other Australian Acts. This paper generally refers to the NSW legislation as representative of the East Coast model, and the WA legislation as representative of the West Coast model. 


\begin{tabular}{|c|c|c|}
\hline Jurisdiction & Legislation & $\begin{array}{c}\text { Date of } \\
\text { Commencement }\end{array}$ \\
\hline NSW & $\begin{array}{l}\text { Building and Construction Industry Security of Payment Act } \\
1999\end{array}$ & 26 March 2000 \\
\hline Victoria & $\begin{array}{l}\text { Building and Construction Industry Security of Payment Act } \\
2002\end{array}$ & 31 January 2003 \\
\hline Queensland & Building and Construction Industry Payments Act 2004 & 1 October 2004 \\
\hline $\begin{array}{l}\text { Western } \\
\text { Australia }\end{array}$ & Construction Contracts Act 2004 & 1 January 2005 \\
\hline $\begin{array}{l}\text { Northern } \\
\text { Territory }\end{array}$ & Construction Contracts (Security of Payments) Act 2004 & 1 July 2005 \\
\hline Tasmania & $\begin{array}{l}\text { Building and Construction Industry Security of Payment Act } \\
2009\end{array}$ & 17 December 2009 \\
\hline ACT & $\begin{array}{l}\text { Building and Construction Industry Security of Payment Act } \\
2009\end{array}$ & 1 July 2010 \\
\hline $\begin{array}{l}\text { South } \\
\text { Australia }\end{array}$ & $\begin{array}{l}\text { Building and Construction Industry Security of Payment Act } \\
2009\end{array}$ & $\begin{array}{l}\text { Yet to be } \\
\text { proclaimed }\end{array}$ \\
\hline
\end{tabular}

Table 1 Construction industry payment legislation in Australia

The key differences between the East and West Coast models have been described by Coggins, Elliott and Bell (2010: 15) as follows:

- The East Coast model Acts provide a detailed statutory payments regime, overriding any inconsistent contractual provisions, which parties undertaking "construction work" or "related goods and services" may choose to engage by submitting a payment claim under the Act at regular intervals and have it responded to within a certain timeframe. Conversely, the West Coast model Acts largely preserve (rather than override) the parties' contractual interim payment regimes.

- The East Coast model Acts only allow for payment claims to be made up the "contractual stream" (typically by a subcontractor against its head contractor, or head contractor against its principal). Conversely, the West Coast model allows for payment claims both up and down the "contractual stream".

- Whilst both models allow for a statutory adjudication scheme to determine, in the interim, disputed payment claims, they differ with respect to adjudicator appointment, submissions which may be considered by an adjudicator, and the approach which an adjudicator is to adopt in order to arrive at his or her determination. In all of these respects the East Coast Acts are more restrictive, disallowing mutual agreement of an adjudicator, consideration of reasons for withholding payment which have not been duly submitted in accordance with the statutory payment scheme, and discouraging an evaluative approach to adjudicators' determinations.

In recent times there has been a strong consensus, and call, from commentators (Bailey 2009; Zhang 2009; Bell \& Vella 2010) - echoing the recommendation of the Cole Royal Commission nearly a decade ago (Cole 2003) - that the legislation should be harmonised into a uniform national approach in order to benefit the construction industry. Accordingly, some commentators have put forward proposals and ideas as to the most appropriate conceptual framework for a unified approach.

After an initial consideration of the objectives of the East and West Coast model legislation and a review of each model's payment systems and adjudication schemes, this paper considers the operation of each model with respect to four key issues - procedural justice, freedom of contract, uptake rates and efficiency. Next, an overview of two existing proposals for harmonisation - one by Davenport (2007) and the other by Bailey (2009) - is given.

Coggins, J (2011) 'From disparity to harmonisation of construction industry payment legislation in Australia: a proposal for a dual process of adjudication based upon size of progress payment claim', Australasian Journal of Construction Economics and Building, 11 (2) 34-59 
Finally, building upon the Davenport and Bailey proposals, a third proposal for harmonisation is proffered by the author.

\section{The Objective of the Legislation}

Despite their differences, the common objective of this raft of legislation, apparent from the Second Reading Speeches for each of the Acts, ${ }^{1}$ is to facilitate the flow of cash in a swift manner down the hierarchical contractual chain on construction projects.

The focus of the Second Reading Speech for the NSW Bill given by the Minister, Mr Morris lemma, was very much on protecting the small subcontractor. Mr lemma (1999: 1594) states:

It is all too frequently the case that small subcontractors - such as bricklayers, carpenters, electricians and plumbers - are not paid for their work. Many of them cannot survive financially when that occurs, with severe consequences for themselves and their families.

Mr lemma (1999: 1595) emphasises the vulnerability of the small subcontractor to payment problems as follows:

Hundreds of subcontractors in New South Wales struggle to survive when they do not receive money owed to them for work undertaken. They do not have the cash flow allowing them to keep on working while waiting for payment. This causes hardship not only to them but also to their families.

However, despite this focus on small subcontractors, the apparent intent of the NSW legislation is far wider ranging affording protection to all parties who carry out work (or supply goods and services) in the construction industry. As Mr lemma (1999: 1595) states:

The bill covers civil engineering as well as architectural work, mechanical and electrical work in buildings, maintenance, and landscaping and decorating. It affects all parties who contract for that work, including owners, contractors, subcontractors and consultants, and applies to both commercial and residential work.

Accordingly, the object of the East Coast model legislation is to ensure contractors or suppliers are entitled to, and are able to recover, progress payment claims for construction work they have undertaken or related goods and services they have supplied (s 3(1) of the NSW Act).

The other Australian Acts have similar wide ranging intent. As noted by Bell and Vella (2010: 568):

Such a [wide-ranging] reform intent is indicated not only...in the Minister's [Mr lemma's] comments, but also in the Second Reading Speeches for the other Australian Acts, and in the objects provisions for the Acts, each of which is widely cast as to the participants within the industry at whom the Act is directed.

In her Second Reading Speech for the WA Construction Contracts Bill, the Minister, Ms MacTiernan (2004: 274), also refers to the vulnerability of subcontractors as follows:

The building and construction industry is made up of many consultants, contractors, subcontractors and suppliers - all of whom work together to deliver buildings and

\footnotetext{
1 ACT (Hargreaves J, 15 October 2009); NSW (lemma M, 29 June 1999); NT (Toyne P, 14 October 2004); Queensland (R E Schwarten, 18 March 2004); SA (Kenyon T, 5 March 2009); Tasmania (Singh L M, 4 November 2009); Victoria (Thomson M R, 21 March 2002); WA (MacTiernan A J, 3 March 2004.

Coggins, J (2011) 'From disparity to harmonisation of construction industry payment legislation in Australia: a proposal for a dual process of adjudication based upon size of progress payment claim', Australasian Journal of Construction Economics and Building, 11 (2) 34-59
} 
infrastructure for the Western Australian economy. This interdependence makes security of payment a vital foundation for the industry. Failure to pay at any link in the contracting chain can be disastrous to those subcontractors and suppliers who are waiting to be paid in their turn and, until now, there has been little recourse available to those who are affected.

Ms MacTiernan (2004: 275) also implies, however, that the WA legislation is intended for a wide range of contractual claims, ranging from small to complex, when she states that the legislation's

primary aim is to keep the money flowing in the contracting chain by enforcing timely payment and sidelining protracted or complex disputes. The process is kept simple, and therefore cheap and accessible, even for small claims.

This is consistent with the West Coast model legislation allowing for either contracting party to apply for adjudication for damages claims, whose recovery is within the scope of the contract provisions, as well as progress payment claims.

\section{Payment Systems and Adjudication Schemes under the Legislation}

The East Coast model operates a 'dual payment' system for progress payment claims, creating a statutory payment system which runs alongside any contractual regime (Beckhaus v Brewarrina Council [2002] NSWSC 960 per Macready AJ at [60]). This dual payment system was described as a "dual railroad track system" by Macready AJ in Transgrid v Siemens \& Anor [2004] NSWSC 87 at [56].

In order to engage the statutory payment system, a claimant must endorse its payment claim as being made under the Act (s 13(2)(c) of the NSW Act), and serve it upon the respondent (s 13(1) of the NSW Act). The West Coast model does not operate a dual payment system, but rather payment claims referred to in the Act are those made under the contractual regime.

The East Coast model provides for recovery of progress payments for construction work undertaken or goods and services supplied only and, therefore, by definition only allows contractors or suppliers to recover payment from their principals (ie, 'upstream' claims). The scope of the West Coast model is wider, providing the right for either party to make an adjudication application in relation to any payment disputes (s 25 of the WA Act) falling within the scope of the building contract, including debts and damages claims.

Under the East Coast model's statutory payment regime, a respondent has up to 10 business days ${ }^{2}$ after the payment claim is served to serve a payment schedule indicating the amount of the payment it proposes to make. If the scheduled amount is less than the claimed amount, the schedule must indicate why the scheduled amount is less with reasons for withholding payment (s 14(3) of the NSW Act). If the respondent either schedules an amount less than the payment claim or fails to pay the whole or part of the scheduled amount by the due date, the claimant may make an adjudication application under the Act ( $\mathrm{s}$ $17(1)$ of the NSW Act).

In the case where a lesser amount is scheduled and paid, the claimant must serve an adjudication application on an Authorised Nominating Authority (ANA) of their choice (s 17(3)(b) of the NSW Act), with a copy served on the respondent (s 17(5) of the NSW Act), within 10 business days after receiving the payment schedule (s 17(3)(c) of the NSW Act). ${ }^{3}$

\footnotetext{
${ }^{2}$ Except in the SA Act which allows 15 business days - see s 14(4)(b)(ii) of the SA Act.

${ }^{3}$ Except in the SA Act which allows 15 business days - see s 17(3)(c) of the SA Act.
} 
The respondent then has either a period of 5 business days ${ }^{4}$ after receiving a copy of the application or 2 business days ${ }^{5}$ after receiving notice of an adjudicator's acceptance of the application, whichever is the later, to lodge an adjudication response with the adjudicator (s 20(1) of the NSW Act).

If the respondent does not duly provide a payment schedule, it becomes liable to pay the claimed amount to the claimant on the due date for the progress payment (s 14(4)(b) of the NSW Act). Where no payment schedule is provided, the claimant has two paths available under the Act by which to recover the payment claim.

The first path is for the claimant to seek summary judgment in court for the debt due (s 15(2)(a)(i) of the NSW Act), in which case the respondent is not entitled to bring any crossclaim against the defendant in the summary judgment proceedings, or raise any defence in relation to matters arising under the construction contract (s 15(4)(b) of the NSW Act). The second path is for the respondent to apply for the payment claim to be determined in adjudication, ${ }^{6}$ in which case the respondent will be disallowed from lodging an adjudication response (s 20(2A) of the NSW Act). This means that a respondent will not then have an opportunity to be heard by an adjudicator who is essentially limited to a consideration of the submissions duly made by the parties (ie, payment claim, payment schedule and all submissions that have been duly made in their support) when determining the adjudication (s 22(2) of the NSW Act).

Even in circumstances where the respondent has duly served a payment schedule, it may only include in its adjudication response reasons for withholding payment which have previously been included in the payment schedule (s 20(2B) of the NSW Act). Thus, a respondent may be prevented from being able to present its full case to the adjudicator unless it has previously served a comprehensive payment schedule which covers all the issues it may wish to rely on subsequently.

Unlike the East Coast model, the West Coast model provides no detailed statutory payment system but rather gives primacy to the parties' agreed contractual payment regime. Thus, where no progress payment is certified in response to a payment claim under the contract within the time stipulated in the contract, the claimant has no statutory right to summary judgment (as per the East Coast model) but must apply to the courts for summary judgment. ${ }^{7}$ If no such payment regime is provided for in the construction contract, then the payment provisions set out in Schedule 1 of the West Coast legislation are implied into the contract.

Unlike the East Coast model, the West Coast legislation does not make the serving of a response to the payment claim $^{8}$ a condition precedent to the right of a party who is served

\footnotetext{
${ }^{4}$ Except in the Tasmanian Act (7 business days) and ACT Act (10 business days).

${ }^{5}$ Except in the Tasmanian Act ( 5 business days) and ACT Act (5 business days).

${ }^{6}$ This second path may be preferable to some claimants in terms of speed of recovery as the claimant may request an adjudication certificate from the relevant ANA stating the adjudicated amount (see s 24 of the NSW Act) and file the adjudication certificate as a judgment for a debt in any court of competent jurisdiction (see $s 25$ of the NSW Act).

${ }^{7}$ If the courts permit summary judgment this does not guarantee swift and inexpensive recovery of a certified payment. There is still the possibility that a defendant may be able to defeat an application for summary judgment by demonstrating to the court that it can mount a reasonable defence by way of a cross claim based upon the facts and law, in which case the only option left to the contractor will be to pursue its claim in a relatively lengthy and costly court trial or arbitration hearing.

${ }^{8}$ le, the equivalent of a "payment schedule" in East Coast terminology. Although under the West Coast legislation a response to a payment claim is a contractual requirement rather than a statutory requirement.
} proposal for a dual process of adjudication based upon size of progress payment claim', Australasian Journal of Construction Economics and Building, 11 (2) 34-59 
with an adjudication application ${ }^{9}$ to lodge an adjudication response. Additionally, there are no limitations as to the inclusion of reasons for withholding payment in a response to an adjudication application. Thus, providing that a party lodges their response to an adjudication application within the time allowed by the legislation (within 14 days (WA Act, s 27(1)) or 10 working days (NT Act, s 29(1)) after the date on which a party to a construction contract is served with an application for adjudication), it will not be deprived of the opportunity to present its full case to the appointed adjudicator.

Furthermore, an adjudicator under the West Coast legislation is not restricted to a consideration of documents submitted by the parties when making his or her determination as in the East Coast model, which in practice means that an adjudicator under the East Coast legislation often makes a determination on documents only. Rather, the legislation encourages a West Coast adjudicator to be more evaluative in their approach to determination by providing that an adjudicator "is not bound by the rules of evidence and may inform himself or herself in any way he or she thinks fit" (s 32(1)(b) of the WA Act) or "appropriate" (s34(1)(b) of the NT Act). This has the effect of extending the adjudicator's investigative powers beyond the consideration of the parties' submissions, thus assisting the adjudicator in ascertaining the facts and the law.

\section{Procedural Justice}

Procedural justice refers to the justice of the processes or methods used to arrive at an outcome or determination. A review of literature in the field of dispute resolution and social psychology shows a strong consensus that procedural justice, or merely the perception of it, has positive consequences (Thibaut \& Walker 1975; Ury, Brett \& Goldberg 1988; Allred 2005) including: a mutual satisfaction of the disputing parties with the outcome; a willingness of the parties to settle; a willingness of the parties to abide by the agreement or determination; and, feelings of trust, cooperation, and commitment toward the other side (see Figure 1). Indeed, it has been shown that procedural justice becomes especially important to disputants when outcomes are unfavourable to them as they may draw some satisfaction from the resolution's fairness (Thibaut \& Walker 1975; LaTour 1978; Greenberg 1987).

A fundamental characteristic of procedural justice in dispute resolution is that both parties have an opportunity to voice their side of the argument, and that both parties feel as though their perspective has at least been considered. Numerous studies have made it clear that the voice effect enhances procedural fairness (Lind, Kanfer \& Earley 1990; Folger 1977; Kanfer, Sawyer, Earley, \& Lind 1987; LaTour 1978; Lind, Kurtz, Musante, Walker, \& Thibaut 1980; Lind, Lissak, \& Conlon 1983; Tyler 1987; Tyler, Rasinski, \& Spodick 1985).

Accordingly it is widely considered to be a fundamental principle in dispute resolution proceedings that each party shall be given a full opportunity to present its case (Article 18 of the United Nations Commission on International Trade Law (UNCITRAL) Model Law on International Commercial Arbitration; Article 6 of the European Convention on Human Rights; s 24 of the Victorian Charter of Human Rights and Responsibilities Act 2006). A strong argument may be made that the East Coast model falls foul of this fundamental principle based upon it:

- not allowing a respondent to include any reasons for withholding payment in its adjudication response unless those reasons have previously been included in the payment schedule (s 20(2B) of the NSW Act); and,

\footnotetext{
${ }^{9}$ le, the equivalent of the "respondent" in East Coast terminology.

Coggins, J (2011) 'From disparity to harmonisation of construction industry payment legislation in Australia: a proposal for a dual process of adjudication based upon size of progress payment claim', Australasian Journal of Construction Economics and Building, 11 (2) 34-59
} 
- barring the respondent from lodging an adjudication response if it has not served a payment schedule within the stipulated timeframe (ie, 10 business days after the payment claim is served except in the SA Act which allows 15 business days).

Indeed, a significant proportion of respondents have lost their right to be heard by an adjudicator on the basis that they have failed to duly serve a payment schedule on the claimant. In Queensland, for example, this proportion amounts to $39 \%$ of all adjudication applications to date in the 2010/11 financial year (Building and Construction Payments Agency 2011).
Antecedents
Consequences

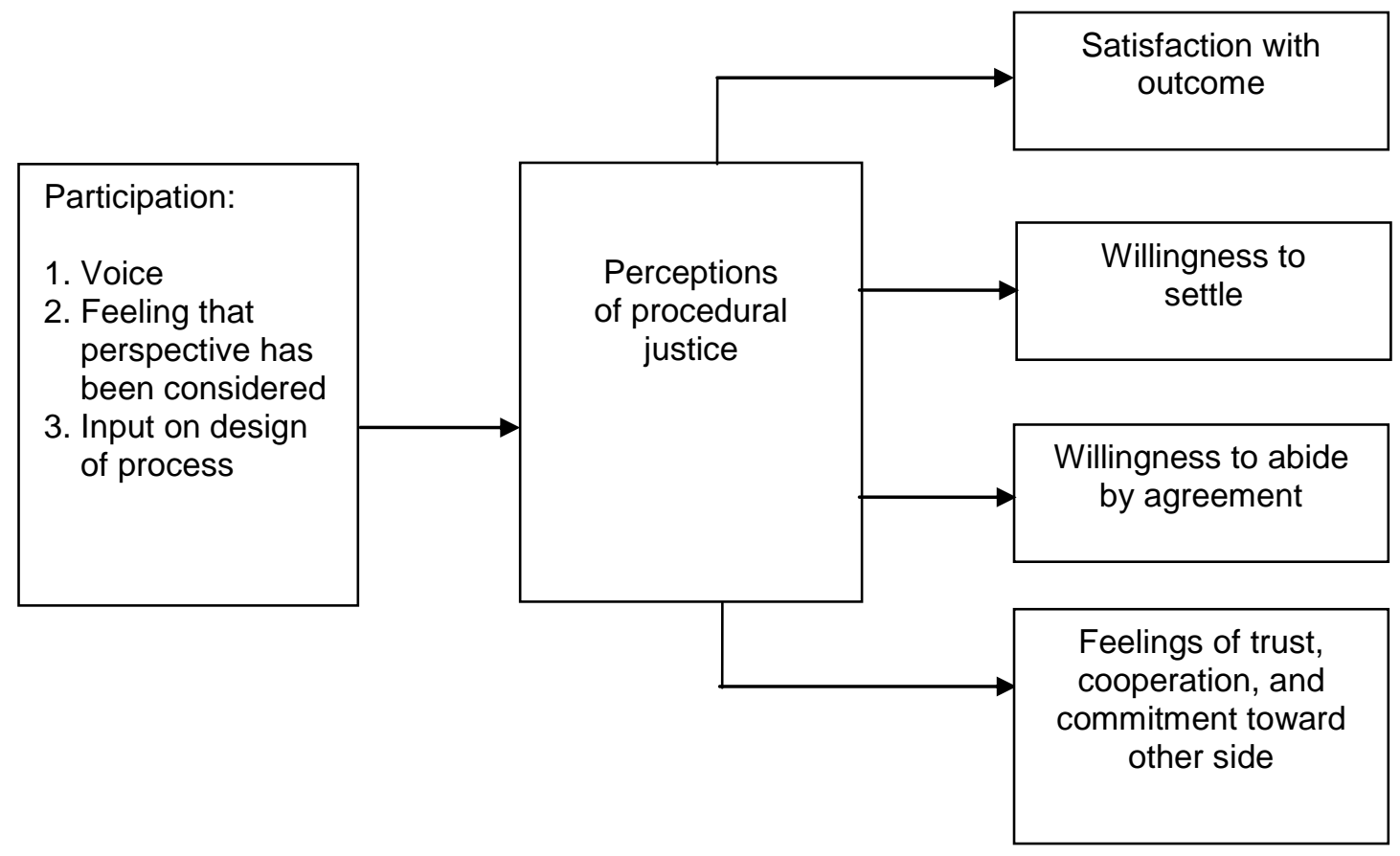

Figure 1 Antecedents and consequences of procedural justice

Source: Allred (2005: 91)

Davenport (2010) argues that the East Coast model's restrictions on respondents being able to have their reasons for withholding payment heard by an adjudicator do not compromise procedural justice. In this respect, Davenport (2010: 10) draws an analogy with formal legal court proceedings, stating: "It [the East Coast model adjudication process] is not very different to the court process. If a defendant fails to lodge a defence, the defendant cannot complain if the claim is decided on the claimant's evidence". It is contended, however, that Davenport's argument overlooks three significant points.

Firstly, statutory adjudication is a form of alternative dispute resolution (ADR), and is not intended to mirror formal court proceedings. As Bowsher $\mathrm{J}$ put it, in the English High Court case of Austin Hall Building Ltd v Buckland Securities Ltd [2001] EWHC Technology 434 at [19]: "Proceedings before an adjudicator are not legal proceedings. They are a process designed to avoid the need for legal proceedings". Thus, in the interests of conducting an ADR process which is procedurally satisfactory to both parties, every possible opportunity should be given to an adjudicator to hear both sides of the argument when determining the outcome of the payment dispute. This would encourage both parties to accept the

Coggins, J (2011) 'From disparity to harmonisation of construction industry payment legislation in Australia: a proposal for a dual process of adjudication based upon size of progress payment claim', Australasian Journal of Construction Economics and Building, 11 (2) 34-59 
adjudicator's determination, and deter a losing party from subsequently pursuing the dispute in court or arbitration - hence achieving the aim of avoiding the need for legal proceedings, the costs of which are ultimately detrimental to all parties associated with the construction industry.

The application of differing requirements with respect to the opportunity to have one's arguments heard in a dispute resolution process, as in this case between litigation and statutory adjudication, is consistent with the court's approach in administrative law that rules of natural justice should be flexible and fair in all the circumstances of a particular case (Aronson, Dyer \& Groves 2004: 468). Such circumstances include a consideration of the nature of the dispute resolution process being used. As stated by Kitto $\mathrm{J}$ in Mobil Oil Australia Pty Ltd v Federal Commissioner of Taxation (1963) 113 CLR 475 at 504: "What the law requires in the discharge of a quasi-judicial function is judicial fairness. That is not a label for any fixed body of rules. What is fair in a given situation depends upon the circumstances". Thus, even if one were to accept Davenport's analogy between the East Coast model's statutory adjudication process and formal court proceedings, the nature and objectives of the dispute resolution processes being used would justify a difference in the content of procedural fairness rules with respect to being given an opportunity to have one's case heard. Litigation is in nature a formal process resulting in a final binding determination, as opposed to the nature of statutory adjudication which is a form of ADR leading to a determination which is binding in the interim. The objective of statutory adjudication, as previously stated, as a form of ADR, should be to avoid the need for legal proceedings.

Secondly, rather than legal proceedings, a more accurate analogy of the East Coast model's statutory adjudication process, as previously observed by Davenport (2007) himself, is that of an independent certification process. With respect to the enforcement of contractual payment certificates in court, the established common law position is to allow a defendant to thwart a plaintiff's application for summary judgement by the raising of a cross-claim for which the defendant can show a reasonable cause of action (Dey $v$ Victorian Railways Commissioners (1949) 78 CLR 62; General Steel Industries Inc v Commissioner for Railways (NSW) (1964) 112 CLR 125), even if such cross-claim is raised for the first time after the date of certification. The courts have adopted this position in order that a defendant who may have a valid case for a cross-claim against a certified contractual payment will not be denied their right to have their case heard before payment is ordered, because to deny such a right would deprive the defendant of both procedural and substantive justice. As Habersberger J stated in Main Roads Construction Pty Ltd v Samary Enterprises Pty Ltd [2005] VSC 388 at [11]:

\begin{abstract}
The power to order summary judgment is one that should be exercised with great care and should never be exercised unless it is clear that there is no real question to be tried. If it is not possible to say without doubt on the whole of the material that there is no question to be tried, there should be leave to defend.
\end{abstract}

This is not dissimilar, in principle, to the situation where a respondent has a valid reason for withholding monies in a payment claim under the East Coast model's payment system, but did not raise the reason in a payment schedule. Indeed, if the East Coast model is viewed as akin to an independent certification process with an adjudicator's determination equating to an independent payment certificate, then a reason for withholding payment raised by a respondent for the first time in its adjudication response would actually be notified to the independent certifier (the adjudicator) within a reasonable amount of time before the independent payment certificate (adjudicator's determination) is due to be issued. Although, as discussed below in further detail, the original object of the East Coast model was not generally for disputed cross-claim amounts for debts or damages (in the form of set offs or back charges) to be subject to adjudication, it should be noted that: in practice some adjudicators are allowing and assessing them (Davenport 2007: 22); and, the East Coast

Coggins, J (2011) 'From disparity to harmonisation of construction industry payment legislation in Australia: a proposal for a dual process of adjudication based upon size of progress payment claim', Australasian Journal of Construction Economics and Building, 11 (2) 34-59 
model does allow for set offs against payment claims for the estimated cost of rectifying any defective work by the contractor (s 10(1)(b)(iv) of the NSW Act).

The problem with the common law position in practice, however, has been that the duration and expense of a full litigation process have been prohibitive to potential plaintiff contractors - thus when a contractor's summary judgment application is denied, the contractor simply cannot afford to pursue its payment claim in a full court trial. This impracticality of the court system has caused injustice to contractors. However, whilst this presents a practical problem at common law due to the inefficiencies of the litigation process, it does not present such a problem if a rapid and inexpensive statutory adjudication process is available to the claimant.

Thirdly, even if one were to accept the proposition that statutory adjudication proceedings were akin to formal court proceedings, as Fenwick Elliott (2010: 4) points out:

There are many reasons why parties may fail to meet a procedural deadline for the lodging of a defence, and courts throughout the common law world allow defendants nevertheless to advance their cases, where appropriate with an accompanying cost order. To do otherwise offends against the fundamental principle of natural justice that both parties should be given the opportunity to be heard.

Procedural justice under the East Coast model is further limited by it restricting an adjudicator to a consideration of documents submitted by the parties when making his or her determination, which in practice means that an adjudicator under the East Coast legislation often makes a determination on documents only. This severely limits the ability of the adjudicator to use their discretion to exercise more procedural flexibility in order to ascertain the pertinent facts and law.

Other issues which restrict procedural justice exist in the East Coast model, including the restriction on parties to agree upon a particular adjudicator, and the restriction on legal representation at conferences (s 21(4A) of the NSW Act). In contrast, the West Coast model allows for the parties to the contract to agree upon a registered adjudicator or prescribed appointer (s 26(1)(c) of the WA Act), and does not specifically preclude legal representation at hearings. Whilst such issues may not be as significant, or affect as many cases, as those previously raised, they may well be highly relevant in large and/or complex cases where the communication of complex legal and factual issues by trained legal counsel, and determination by a mutually respected adjudicator, would give the parties confidence in the outcome.

The more restrictive, and less procedurally just, design of the East Coast, as compared to the West Coast, adjudication process can be explained by the more limited scope of the East Coast legislation. The East Coast legislation was only intended to cover "purely progress payment claims' (Davenport 2007: 15). Consequently, the East Coast adjudication scheme was designed solely for the valuation of construction work undertaken or related goods and services supplied. As submitted by Brand and Davenport (2010: 5), the East Coast adjudication scheme was not intended (and, therefore, designed) to accommodate more complex claims for monies due under the contract such as, for example, delay damages claims by a contractor or liquidated damages claims which the principal, or their contract administrator, may set off against a progress claim. Accordingly Davenport (2007: 23) states "adjudication of a progress claim is a fast track process that is not suitable for deciding issues of breach of contract, extensions of time, repudiation and termination, causation, quantification of damages etc.".

Consequently, the role of the adjudicator under the East Coast process is essentially limited to determining a progress claim amount by assessing the quantity of construction work undertaken (or related goods and services supplied) and whether such work (or goods and

Coggins, J (2011) 'From disparity to harmonisation of construction industry payment legislation in Australia: a proposal for a dual process of adjudication based upon size of progress payment claim', Australasian Journal of Construction Economics and Building, 11 (2) 34-59 
services) accord with the contract requirements in terms of scope and quality, and valuing such work at the applicable contract prices or rates (s 10(1)(b)(i), (ii) \& (iii) of the NSW Act). It is worth reiterating here that the East Coast legislation does provide for statutory set off in one respect: the estimated cost of rectifying any defective work by the contractor (s $10(1)(b)$ (iv) of the NSW Act), the evaluation of which is consistent with the adjudicator's general role as assessor of quantity and quality of work.

The difference in progress payment amount between the statutory entitlement, as determined by the adjudicator under the East Coast legislation, and the contractual entitlement, as determined by the contract administrator, appears to have resulted in some confusion and inconsistency with respect to what amounts should or should not be included in an adjudicator's determination. Accordingly, with respect to set offs under the current East Coast adjudication process, Davenport (2007: 22) states:

\begin{abstract}
There are differences in the approach taken by adjudicators. Some take the approach that only a debt (owed to the purchaser) that is admitted by the supplier or has been decided by a court or tribunal or in arbitration or has been created under a dispute resolution clause in the contract, can be set off against progress payments... Other adjudicators decide disputed issues of liability for and quantum of the back charges... Some adjudicators allow a set off of an amount claimed by the purchaser even if liability and quantum have not been proven.
\end{abstract}

Furthermore, the NSW judiciary has allowed claimants to recover amounts for delay damages in adjudicated payment claims under the Act. ${ }^{10}$ According to Davenport (2007: 14) and Davenport \& Brand (2010: 5), this creates an "imbalance" as only one party is allowed to apply for adjudication of payment disputes regarding damages. As claims for damages falling within the scope of the contract (eg, contractors' claims for delay and disruption costs caused by principals, and principals' claims for liquidated or general damages for contractor's delay in achieving practical completion) have the potential to be made by either contractual party, it is procedurally unfair to allow only one party the right to refer such claims to the Act's dispute resolution processes.

Thus, whilst the East Coast legislation may not have been originally designed or intended to resolve disputes regarding claims for debts or damages, it is currently being used for this purpose.

Consequently, notwithstanding the reason for the more restrictive adjudication scheme of the East Coast model, its inherent lack of procedural justice is likely having significant impacts upon substantive, or distributive, justice. It may be considered as somewhat disconcerting, therefore, that multi-million dollar progress claim disputes are being resolved, albeit on an interim basis, by means of a fast track adjudication scheme which limits the adjudicator's power to investigate and potentially bars a respondent from having its arguments heard by the adjudicator.

\title{
Restriction on Freedom of Contract
}

As noted by Bell \& Vella (2010: 569), the UK legislation, which is a lot less regulatory in nature than the East Coast legislation, has been criticised as representing an unjustified incursion into freedom of contract. In this respect, as noted by Bell and Vella (2010: 569), Lloyd (2001: 448) commented in relation to the way in which coverage of the UK Act was framed:

\footnotetext{
10 See Coordinated Construction Co Pty Ltd v JM Hargreaves Pty Ltd [2005] NSWCA 228; Coordinated Construction Co Pty Ltd v Climatech (Canberra) Pty Ltd \& Ors . [2005] NSWCA 229; Minister for Commerce (formerly Public Works \& Services) v Contrax Plumbing (NSW) Pty Ltd \& Ors [2005] NSWCA 142; and, John Holland Pty Limited $v$ Roads \& Traffic Authority of New South Wales \& Ors [2007] NSWCA 19.
}

Coggins, J (2011) 'From disparity to harmonisation of construction industry payment legislation in Australia: a proposal for a dual process of adjudication based upon size of progress payment claim', Australasian Journal of Construction Economics and Building, 11 (2) 34-59 
It is hard to think of another comparable case of Parliament singling out parts of a sector of the commercial life of the country and requiring them to alter their contracts... on the basis that it knew better than its members how their commercial relationships should be regulated. It is a remarkable interference in the freedom of contract enjoyed by people who are normally well able to look after themselves.

Further, as noted by Bell and Vella (2010: 569), Duncan Wallace (1999: 21) was particularly critical of the UK Act's application as between the principal and the main (or head) contractor:

Here adjudication does not fill a gap, as it might be said to do in... sub-contracts... but it quite simply abrogates at a stroke the long-established machinery of professional administrative regulation during the construction period, subject to later arbitration or litigation, which has evolved and been implemented by most commonly used forms of main contract in England and the Commonwealth for over a century.

The undermining of the traditional independent contractual payment certification process by the contract administrator, provided for in the vast majority of standard forms of construction contracts, is indeed a common feature to all the enacted construction industry payment legislation. The legislation adopts a 'one-size fits all' approach rather than targeting those lower hierarchical tiers of the contractual chain where traditional independent contractual payment certification mechanisms are not commonly provided.

This is the case despite there seeming to be little evidence to support a 'one-size fits all' approach. Accordingly, albeit in the English context, Duncan Wallace (1999: 21) points out that in the Latham Report (Latham 1994), the catalyst for the UK Act, the only evidentiary basis in support of alleged bias or unfairness in the contractual payment traditional system relates to the quite different sub-contract setting, and not the principal/head contractor setting.

Towards the top of the contractual chain are those parties (principal, head contractors and large sub-contractors) who are more likely to have equality of bargaining power with each other, and have entered into contracts which provide for an independent payment certification process by a contract administrator. Conversely, towards the bottom of the chain are those parties (medium and small sized sub-contractors) who are more likely to have inequality of bargaining power with their principals, and have entered into contracts which do not provide for an independent payment certification process by a contract administrator. Accordingly, Fenwick Elliott (2010: 2) observes:

It is certainly true that... head contracts frequently provided for an architect or engineer to act as certifier, but there was no history of any such arrangements being applied down the contractual chain to the case of subcontracts, where individual tradesmen were in any position analogous to employees.

Whilst the application of statutory mandatory adjudication to the whole contractual chain may be regarded as contentious, the situation under the East Coast model is compounded further still by the provision for a highly regulatory dual payment system (i.e., statutory payment scheme alongside contractual payment scheme) which has the potential to override several freely agreed contractual provisions relating to payment (e.g., provisions regarding making claims for payment, responding to claims for payment and time for payment).

Furthermore, s 34 of the NSW Act, and its equivalent in the other East Coast Acts, provides:

(1) The provisions of this Act have effect despite any provision to the contrary in any contract. 
(2) A provision of any agreement (whether in writing or not):

(a) under which the operation of this Act is, or is purported to be, excluded, modified or restricted (or that has the effect of excluding, modifying or restricting the operation of this Act), or

(b) that may reasonably be construed as an attempt to deter a person from taking action under this Act,

is void.

The scope of $s 34$, and its potential to be an incursion on freedom of contract, is still unknown. ${ }^{11}$ Indications from the NSW judiciary to date suggest that the operation of $s 34$ will depend upon a contractual provision's degree of inimicality upon the relevant statutory provision. For example, Hodgson JA stated in Minister for Commerce $v$ Contrax Plumbing [2004] NSWCA 142 at [54]:

in my opinion a provision of a contract as to the determination of reference dates, or as to the calculation of the amount of progress payments, could be such as to restrict the operation of the Act within the meaning of s.34, even though the Act in s.8(2)(a) and s.9(a) expressly defers to such provisions. For example, if a contract provided for yearly reference dates, or provided that progress payments should be calculated on the basis of $1 \%$ of the value of work done, in my opinion such provisions could be so inimical to s.3(1), s.3(2) and s.8(1) as to be avoided by s.34.

There seems little doubt, however, that s 34 has eroded freedom of contract. Accordingly, McDougall (2006) states:

s.34 will operate in all circumstances where contractual clauses attempt to eradicate or limit the rights given under the Act. As a result, the section is likely to alter the effect of numerous contractual provisions.

Additionally, if the true intent of the East Coast legislation were followed, and damages falling within the scope of the contract were to be excluded from progress payments, the East Coast legislation may entitle a claimant to adjudicated amounts that are not in fact due as agreed under the contract.

Whilst the West Coast model imposes statutory adjudication upon the entire contractual chain, it otherwise generally endeavours to preserve freedom of contract. ${ }^{12}$ As stated by Ms MacTiernan (2004: 275) in her Second Reading speech for the WA Construction Contracts Bill:

The Bill draws on legislation already enacted in the United Kingdom, New South Wales and Victoria, but has been drafted to overcome a number of problems that have become apparent in those jurisdictions. In particular, it is based on enforcing the contract between the parties and does not introduce a separate, and possibly conflicting, statutory right to payment.

\footnotetext{
${ }^{11}$ For decisions considering the effect of $s$ 34, see Minister for Commerce $v$ Contrax Plumbing[2004] NSWSC 823; John Goss Projects v Leighton Contractors Pty Ltd \& Davenport [2006] NSWSC 798; and, John Holland Pty Ltd $v$ Roads and Traffic Authority of New South Wales [2006] NSWSC 874.

${ }^{12}$ Although the West Coast legislation is not totally without regulation on the contractual payment system. For example, the West Coast legislation prevents the period between payment claim and payment from being any longer than 50 days - see s 10 of the WA Act.
} 
The degree of regulation afforded by the East Coast model, therefore, is significantly more than that imposed by the UK Act or the West Coast model.

It is also worth noting here that the regulatory nature of the East Coast model is at odds with the approach of the judiciary in recent times which has conspicuously refrained from interfering with freedom of contract even in cases where a contractual term may appear, at first sight, to be harsh (Multiplex Constructions (UK) Ltd v. Honeywell Control Systems Ltd (No.2) [2007] EWHC 447 (TCC); Ringrow Pty Ltd v BP Australia Pty Ltd [2005] HCA 71; State of Tasmania v Leighton Contractors Pty Ltd [2005] TASSC 133). Accordingly, their Honours (Gleeson CJ, Gummow, Kirby, Hayne, Callinan and Heydon JJ) in Ringrow Pty Ltd v BP Australia Pty Ltd [2005] HCA 71 at [31] and [32] stated:

The law of contract normally upholds the freedom of parties, with no relevant disability, to agree upon the terms of their future relationships... Exceptions from that freedom of contract require good reason to attract judicial intervention to set aside the bargains upon which parties of full capacity have agreed.

It may be argued that the highly regulatory nature of the East Coast model is akin to that usually found in legislation enacted to protect vulnerable individual consumers and employees. Indeed, Davenport (2010: 2-3) draws parallels between construction industry payment legislation and protection afforded to employees under industrial relations legislation ( s 118(1) of the Industrial Relations Act 1996 (NSW), and s 323(1) of the Fair Work Act (Cth)), and notes that similar protection was not available for contractors who were not employees until the East Coast legislation was enacted.

However, even if one were to accept that such regulatory legislation was justified in the context of small subcontractors, it would seem extraordinary that legislation akin to that of employee protection legislation should be extrapolated to protect contractors throughout the whole industry regardless of size. Nevertheless, it is the case that the East Coast model with all its regulations, curbs on freedom of contract, and restrictions on procedural justice is being used by contractors to make payment claims for tens of millions of dollars. ${ }^{13}$

\section{Uptake Rates}

Table 2 shows the total number of adjudication applications lodged in the four jurisdictions of NSW, Queensland, Victoria and WA since commencement of the respective Acts. ${ }^{14}$

The table shows that there has been a significant use of statutory adjudication in NSW and Queensland since commencement of the legislation. In contrast, however, statutory adjudication under the Victorian Act has been used very little. The Victorian Act deviates the most from the other East Coast Acts particularly with respect to making certain matters "excluded amounts" from payment claims, as discussed in further detail by Bell and Vella (2010: 574). It is, perhaps, such complexities in the Victorian Act which have deterred usage.

In 2009/10 there were 999 adjudication applications in Queensland (Building and Construction Industry Payments Agency 2010). In 2008, there were 940 adjudication applications in NSW (NSW Procurement, NSW Department of Commerce. Data obtained upon request). In 2008/09, there were 105 adjudication applications made in WA (Construction Contracts Registrar (WA) 2009).

\footnotetext{
${ }^{13}$ According to the Queensland Building and Construction Industry Payments Agency Report June 2009: 62 of the determined adjudications in 2008/2009 involved payment claims in excess of $\$ 500,000$, and the largest payment claim, for which an adjudicator's decision had been released, was in the amount of $\$ 16,094,294$. Data obtained from the NSW Department of Commerce shows maximum payment claims of almost $\$ 83.4$ million in 2005, \$93.9 million in 2006, \$26.7 million in 2007, and \$9.3 million in 2008.

${ }^{14}$ In the case of NSW, since commencement of the amended Act in March 2003.
}

Coggins, J (2011) 'From disparity to harmonisation of construction industry payment legislation in Australia: a proposal for a dual process of adjudication based upon size of progress payment claim', Australasian Journal of Construction Economics and Building, 11 (2) 34-59 
When comparing these figures, the relative size of population and economy of each jurisdiction should be considered. Queensland's population is around 95\% larger (Australian Bureau of Statistics 2010), and final demand around 65\% larger (Australian Bureau of Statistics 2009), than WA's. NSW population is $215 \%$ larger (Australian Bureau of Statistics 2010), and final demand around 150\% larger (Australian Bureau of Statistics 2009), than WA's. Based upon the annual adjudication application figures quoted above, the number of annual adjudication applications in Queensland is $850 \%$, and in NSW is $795 \%$, more than in WA. Therefore, even when adjusting for population and economy, it can be seen that statutory adjudication is being used to a far greater extent in Queensland and NSW than in WA.

The Building Services Authority (Qld) (2010: 10) observes that "the average payment claim proceeding to adjudication in Queensland is only 29\% (\$264,493) of the average payment claim proceeding to adjudication in WA $(\$ 902,280) "$, and notes that this means that adjudication under the Queensland Act is being used by many more small to medium size contractors and suppliers than are using adjudication under the WA Act. However, the mean WA payment claim figure quoted by the Building Services Authority (QId) does not appear to accord with that of $\$ 341,324^{15}$ reported by the Construction Contracts Registrar (WA) (2009) for payment claims made in $2008 / 2009$, which would mean that the average payment claim in Queensland for $2008 / 2009^{16}$ was $69 \%$ of that in WA.

\begin{tabular}{|l|c|c|c|c|}
\hline & $\begin{array}{c}\text { New South Wales } \\
\text { (amended Act } \\
\text { commenced March } \\
\text { 2003, calendar } \\
\text { years 2003-2009) }\end{array}$ & $\begin{array}{c}\text { Queensland } \\
\text { (commenced } \\
\text { October 2004, } \\
\text { calendar years up } \\
\text { to December } \\
\text { 2009) }\end{array}$ & $\begin{array}{c}\text { Victoria } \\
\text { (commenced } \\
\text { 2002, calendar } \\
\text { years 2002- } \\
\text { 2009) }\end{array}$ & $\begin{array}{c}\text { Western } \\
\text { Australia } \\
\text { (commenced } \\
\text { 2005, calendar } \\
\text { years up to } \\
\text { December 2009) }\end{array}$ \\
\hline $\begin{array}{l}\text { Applications } \\
\text { Lodged }\end{array}$ & 5877 & 2760 & 258 & 307 \\
\hline $\begin{array}{l}\text { Total Claim } \\
\text { Value (rounded } \\
\text { up) }\end{array}$ & $\mathbf{\$ 2 . 5}$ billion & $\mathbf{\$ 7 3 0 \text { million }}$ & $\mathbf{\$ 1 5 2 \text { million }}$ & $\mathbf{\$ 2 7 7 \text { million }}$ \\
\hline
\end{tabular}

Table 2 Use of rapid adjudication - Interstate comparison ${ }^{17}$

Source: Building Services Authority (QId) (2010: 8)

The Building Services Authority (QId) (2010: 10) also notes that "under the BCIPA for the 2008/2009 financial year, of the 754 decided adjudication matters, 463 (61\%) were in respect of payment claims under $\$ 40,000 "$.

The data presented in Table 3 shows that in 2008/2009, 52\% of all adjudicated payment claims in Queensland were for less than $\$ 25,000$, whereas in WA $30 \%$ of all payment claims lodged were for less than $\$ 25,000$.

\footnotetext{
15 Even when the mean payment claim calculation is adjusted to exclude payment claims dismissed and withdrawn, the result is still only $\$ 347,712$.

${ }^{16}$ Using the figure of $\$ 234,800$ reported by the Building and Construction Industry Payments Agency (2009).

${ }^{17}$ Note: The Queensland Building Services Authority did not consider the NT Act in this analysis because of the very small number of adjudications received over its $51 / 2$ years of operation.
}

Coggins, J (2011) 'From disparity to harmonisation of construction industry payment legislation in Australia: a proposal for a dual process of adjudication based upon size of progress payment claim', Australasian Journal of Construction Economics and Building, 11 (2) 34-59 


\begin{tabular}{|c|c|c|c|c|}
\hline \multirow{2}{*}{ Range of Claims } & \multicolumn{2}{|c|}{$\begin{array}{c}\text { Queensland } \\
\text { (Building and Construction Industry } \\
\text { Payments Agency 2009) }\end{array}$} & \multicolumn{2}{|c|}{$\begin{array}{c}\text { Western Australia } \\
\text { Construction Contracts Registrar } \\
\text { (WA) (2009) }\end{array}$} \\
\cline { 2 - 5 } & $\begin{array}{c}\text { Number of } \\
\text { Adjudication } \\
\text { Decisions } \\
\text { Released }\end{array}$ & $\begin{array}{c}\text { Percentage of } \\
\text { Total Adjudication } \\
\text { Decisions }\end{array}$ & $\begin{array}{c}\text { Number of } \\
\text { Adjudication } \\
\text { Applications } \\
\text { Lodged }\end{array}$ & $\begin{array}{c}\text { Percentage of } \\
\text { Total Adjudication } \\
\text { Applications } \\
\text { lodged }\end{array}$ \\
\hline$\$ 0-\$ 9,999$ & 241 & $32 \%$ & 19 & $18 \%$ \\
\hline$\$ 10,000-\$ 24,999$ & 150 & $20 \%$ & 13 & $12 \%$ \\
\hline$\$ 25,000-\$ 99,999$ & 185 & $25 \%$ & 27 & $26 \%$ \\
\hline$\$ 100,000-\$ 249,999$ & 79 & $10 \%$ & 12 & $12 \%$ \\
\hline$\$ 250,000-\$ 499,999$ & 37 & $5 \%$ & 15 & $14 \%$ \\
\hline$>\$ 500,000$ & 62 & $8 \%$ & 19 & $18 \%$ \\
\hline Total & 754 & $100 \%$ & 105 & $100 \%$ \\
\hline
\end{tabular}

Table 3 Number of adjudications by claim value in Queensland and WA, 2008/2009 ${ }^{18}$

\section{Efficiency of Adjudication Process}

The efficiency of each of the legislative models is considered with respect to adjudication fees, duration of the adjudication processes, and the volume of litigation resulting from statutory adjudication.

\section{Adjudication Fees}

Table 4 shows the mean adjudication fees for a various ranges of payment claim sizes in 2008/2009 as reported by the Building and Construction Industry Payments Agency (2009) and the Construction Contracts Registrar (WA) (2009).

\begin{tabular}{|l|c|c|}
\hline \multirow{2}{*}{ Range of Claims } & \multicolumn{2}{|c|}{ Mean fees for Adjudication } \\
\cline { 2 - 3 } & Queensland & Western Australia \\
\hline$\$ 0-\$ 9,999$ & $\$ 919$ & $\$ 1,364$ \\
\hline$\$ 10,000-\$ 24,999$ & $\$ 1,836$ & $\$ 2,653$ \\
\hline$\$ 25,000-\$ 99,999$ & $\$ 3,432$ & $\$ 2,650$ \\
\hline$\$ 100,000-\$ 249,999$ & $\$ 6,123$ & $\$ 6,133$ \\
\hline$\$ 250,000-\$ 499,999$ & $\$ 9,029$ & $\$ 3,923$ \\
\hline$>\$ 500,000$ & $\$ 16,324$ & $\$ 6,065$ \\
\hline
\end{tabular}

Table 4 Mean adjudication fees reported in Queensland and WA in 2008/2009

It must be noted that these mean adjudication figures are not directly comparable as the WA figures have been calculated based upon the total number of adjudication applications received during the year, ${ }^{19}$ whereas the Queensland figures have been calculated based upon the number of adjudication decisions released. Therefore, these figures can only be

\footnotetext{
${ }^{18}$ Although not a direct comparison - the Queensland figures are for adjudication decisions released and the WA figures are for adjudication applications lodged - these figures provide an indicative measure of the proportionate numbers of adjudications at each claim value.

${ }^{19}$ Of the 105 applications received in WA, 37 were either dismissed withdrawn or are pending.
}

Coggins, J (2011) 'From disparity to harmonisation of construction industry payment legislation in Australia: a proposal for a dual process of adjudication based upon size of progress payment claim', Australasian Journal of Construction Economics and Building, 11 (2) 34-59 
treated as indicative as to comparative levels of adjudication fee. It may be observed from the figures that adjudication fees are low in both jurisdictions. Mean adjudication fees are at least around $45 \%$ lower in Queensland for payment claims below $\$ 25,000$. However, for larger payment claims mean adjudication fees between the two jurisdictions would appear to be more on an equal footing or, if anything, more expensive in Queensland. ${ }^{20}$

\section{Duration of Adjudication Scheme}

Practically, there is little difference in the time allowed for an adjudicator to make his or her determination between the East Coast and West Coast models. The East Coast model requires determination within 10 business days (s 21(3) of the NSW Act), whereas the WA Act requires determination within 14 days (s 31(1) of the WA Act). ${ }^{21}$ There is a difference, however, in timing with respect to the period which a respondent has to serve a response to the adjudication application.

Under the East Coast model a respondent has to lodge its adjudication response within 5 business days after receiving the claimant's adjudication application or 2 business days after receiving notice of the adjudicator's acceptance of the adjudication application, whichever is the later (s 20(1) of the NSW Act). Thus, assuming an adjudication response is lodged 5 business days after the adjudication application is received by the respondent and the adjudicator notifies their acceptance of the pplication in a timely fashion, ${ }^{22}$ the whole adjudication process from application to determination (presuming the adjudicator takes the full 10 business days to make their determination) takes 15 business days (or 3 weeks).

The West Coast model allows the respondent 14 days $^{23}$ (s 27(1) of the WA Act) from the date on which the adjudication application was served to prepare and serve its adjudication response. Thus, assuming an adjudication response is lodged by the respondent 14 days after the serving of the adjudication application, the whole adjudication process from application to determination (presuming the adjudicator takes the full 14 days to make their determination) takes 28 days (or 4 weeks).

Under the East Coast model's payment system, as described above, if the respondent takes the full 10 business days ${ }^{24}$ permitted after the payment claim is served to lodge a payment schedule, the soonest which an adjudication application can be lodged is on the $11^{\text {th }}$ business day after the payment claim is served. Thus, the minimum period of time from payment claim to adjudication determination will be approximately 5 weeks. In the case where a respondent fails to serve a payment schedule and is given a second chance to do so by the claimant who chooses to apply for adjudication (s 17(2) of the NSW Act), this period of time extends to around 6 weeks.

Under the West Coast model there is, of course, no statutory payment system. Therefore, the minimum period of time between a payment claim and an adjudication application will be

\footnotetext{
${ }^{20}$ However, such comparison for larger claim ranges must be treated with caution due to the outlier effect. Accordingly, in Queensland the maximum single payment claim with a decision released in 2008/2009 was in the amount of $\$ 16,094,294$, whereas, in WA it was $\$ 4,464,818$.

${ }^{21}$ The WA Act does not define 'day'. However, s 61(1)(e) of the Interpretation Act (WA) 1984 states that where the time limited for the doing of a thing expires or falls upon a Saturday, Sunday or public holiday, the thing may be done on the next day that is not an excluded day.

${ }^{22}$ Under s 21(3) of the NSW Act, the start of the adjudication termination period is triggered by the adjudicator's notice of acceptance. In practice this may mean that the determination period may commence before the adjudication response has been lodged. However, the adjudication determination period is triggered by the serving of the adjudication response under the Queensland, SA, Tasmanian, ACT, WA and NT Acts.

${ }^{23} \mathrm{~S} 29(1)$ of NT Act allows 10 working days.

${ }^{24} 15$ business days under the SA Act s 14(4)(b)(ii).
}

Coggins, J (2011) 'From disparity to harmonisation of construction industry payment legislation in Australia: a proposal for a dual process of adjudication based upon size of progress payment claim', Australasian Journal of Construction Economics and Building, 11 (2) 34-59 
subject to the contractually agreed payment provisions. The West Coast model provides that a party must apply for adjudication within 28 days after a dispute arises (s 26(1) of the WA Act). A dispute arises if by the time when the amount claimed in a payment claim is due to be paid under the contract, the amount has not been paid in full, or the claim has been rejected or wholly or partly disputed (s 6(a) of the WA Act). Under a typical standard form of building contract conditions, such as the Australian Standard General conditions of contract (AS 2124-1992), the principal has a period of 14 days after receipt of the payment claim to issue a payment certificate (which shall contain any reasons for withholding payment) and a further 14 days to pay the contractor. ${ }^{25}$ Thus, the minimum period of time from payment claim to adjudication determination will be approximately 6 weeks where the contractor disputes the certified amount, ${ }^{26}$ and 8 weeks where the principal fails to pay the certified amount.

Thus, it may be seen that an adjudication determination will generally take 1 to 2 weeks longer to obtain under the West Coast model as compared to the East Coast model. In the interests of achieving more procedural justice in a determination, 1 to 2 weeks extra is a relatively small price to pay. However, for small contractors whose commercial survival may be dependent on timely payment of relatively small claims, 1 to 2 weeks may indeed make a significant difference. Further, small contractors nearer the bottom of the hierarchical contractual chain are more likely to be vulnerable to unfavourable contract payment terms, due to their weaker bargaining position, which may extend the period between the date of claim and date of payment beyond those normally found in standard forms of building contracts.

\section{Litigation}

Since its commencement, the NSW Act has generated a significant amount of litigation. Since 2001, there have been well in excess of 200 judgments emanating from the NSW Supreme Court and Court of Appeal in relation to the NSW Act. The majority of these judgments concern cases where a respondent has attempted to have an adjudicator's determination, or part thereof, set aside. Invariably, the judgments have concerned adjudicator determinations of significant amounts (usually, at least, hundreds of thousands of dollars).

The numbers of such applications show little sign of abatement, with at least 21 judgments ${ }^{27}$ coming out of the NSW Supreme Court, and 4 out of the NSW Court of Appeal, in 2009 concerning, for one reason or another, challenges to the payment of an amount determined in adjudication. A significant proportion of these applications have been made on the basis that either a payment claim $^{28}$ or payment schedule $^{29}$ has not been validly served in accordance with the Act's dual payment system.

\footnotetext{
${ }^{25}$ If no such timeframes are provided for in the building contract then the West Coast model implies the following provisions: a notice of dispute (stating reasons for disputing the claim) must be given within 14 days of the payment claim, and the due date for payment of any undisputed claim (or portion thereof) is 28 days after the payment claim is received by the paying party - see Schedule 1, Division 5 of the WA Act.

${ }^{26}$ Assuming the certificate containing reasons for withholding payment is issued at the end of the contractually prescribed period.

27 This figure was obtained by conducting a search on the NSW Lawlink Case Law website $<$ http//:www.lawlink.nsw.gov.au/lawlink/caselaw/ll_caselaw.nsf/cases/cl_sc > using the keywords "Building and Construction Industry Security of Payment Act". The figure is indicative and not necessarily a fully accurate number of the total judgments in 2009.

${ }^{28} 5$ of the 21 cases referred to above in 2009 concerned whether the payment claim (in full or in part) was valid: see The Owners Strata Plan 56587 v Consolidated Quality Projects [2009] NSWSC 1476 ; Allpro Building Services v C\&V Engineering Services [2009] NSWSC 1247; Urban Traders v Paul Michael [2009] NSWSC 1072; The University of Sydney v Cadence Australia Pty Limited \& Anor [2009] NSWSC 635; Perform (NSW) Pty Ltd v Mev-Aus Pty Ltd trading as Novatec Construction Systems [2009] NSWSC 416.
}

Coggins, J (2011) 'From disparity to harmonisation of construction industry payment legislation in Australia: a proposal for a dual process of adjudication based upon size of progress payment claim', Australasian Journal of Construction Economics and Building, 11 (2) 34-59 
Furthermore, following the NSW Court of Appeal's recent judgment in Chase Oyster Bar $v$ Hamo Industries [2010] NSWCA 190, which may have reopened the door ${ }^{30}$ for adjudicators' determinations to be amenable to orders in the nature of certiorari, there would now appear to be an increase in the potential scope of grounds ${ }^{31}$ upon which a disgruntled party could mount a challenge to an adjudicator's determination. It remains to be seen, however, whether the Chase Oyster Bar decision will encourage an increase in the amounts of challenges in NSW.

There has been a total of three WA Supreme Court judgments (and no WA Court of Appeal judgments) in relation to issues concerning the WA Act since its enactment in 2004, only one (O'Donnell Griffin Pty Ltd v John Holland Pty Ltd [2009] WASC 19 ) of which concerned an application to have the adjudicator's determination set aside. ${ }^{32}$

The relatively large amount of litigation arising from the NSW model detracts from the efficiency of statutory adjudication as a dispute resolution process for payment claims in the construction industry due to the resultant increased transaction costs, defined as "the time, money, and emotional energy expended in disputing, the resources consumed and destroyed, and the opportunities lost" (Ury, Brett \& Goldberg 1988: 11), in resolving such disputes. Additionally, it may be indicative of a lack of confidence which adjudication users have in the adjudication process to deliver accurate and fair outcomes.

\section{Overview of Existing Proposals for Harmonisation}

\section{Davenport's Proposal for a Dual Process of Adjudication}

Davenport (2007) has proposed a dual process of adjudication which aims to combine the East Coast and West Coast model statutory adjudication processes in order to "solve many of the perceived problems with adjudication in the building and construction industry" (Davenport 2007: 12). This proposed dual process has been further discussed by Brand \& Davenport (2010).

\section{Davenport (2007: 15) states that:}

The proposed dual process would retain the [East Coast] certification process for purely progress payment claims, i.e. for claims for the value of work, goods or services that have actually been provided, and would adopt the traditional [West Coast] process for other payment disputes.

Davenport (2007: 16-17) cites examples of such 'other payment disputes', which he terms 'ex-contractual claims', including, inter alia: a contractor's claim for delay damages for breach of contract by the principal, a contractor's claim for the value of extra work carried out for which the superintendent refuses to direct a variation in writing, a principal's claim for

\footnotetext{
${ }^{29} 2$ of the 21 cases referred to above in 2009 concerned whether the payment schedule was validly served: see Perform (NSW) Pty Ltd v Mev-Aus Pty Ltd trading as Novatec Construction Systems [2009] NSWSC 416, and Lucas Stuart v Hemmes Hermitage [2009] NSWSC 477.

${ }^{30}$ A 'door' that was previously shut by the NSW Court of Appeal in Brodyn Pty Ltd (t/as Time, Cost and Quality) $v$ Davenport (2004) 61 NSWLR 421.

31 Beyond the "basic and essential" requirements" listed in Brodyn Pty Ltd (t/as Time, Cost and Quality) $v$ Davenport (2004) 61 NSWLR 421 at [53].

32 Note that a search on the WA State Administrative Tribunal (SAT) decisions database website <http://decisions.justice.wa.gov.au/SAT/SATdcsn.nsf> revealed that there have been 34 SAT judgments since the enactment of the WA Act in 2004. However, most of these judgments concern a review of an adjudicator's decision to dismiss an adjudication application without making a determination of its merits (see $s 31$ (2)(a) \& $s$ 46(1) of the WA Act). SAT has made it clear it will only review adjudicators' decisions with respect to jurisdiction, and that it will not review an adjudicator's determination on the merits - for example, see Match Projects Pty Ltd and Arcon (WA) Pty Ltd [2009] WASAT 134.
}

Coggins, J (2011) 'From disparity to harmonisation of construction industry payment legislation in Australia: a proposal for a dual process of adjudication based upon size of progress payment claim', Australasian Journal of Construction Economics and Building, 11 (2) 34-59 
liquidated or general damages for delay in achieving practical completion, and a principal's claim for the costs of having work carried out under the contract, which the contractor disagrees is included in the contract, by another contractor.

Davenport (2007: 15) explains that his proposed dual process of adjudication 'would be basically the same as now exists but with slightly different rules for dealing with progress claims and ex-contractual claims'.

This would, thus, allow an adjudication process which is faster-track, cheaper and significantly more restrictive on the investigative powers of the adjudicator for purely progress payment claims, and a quasi-judicial adjudication process for adjudication of excontractual claims where, as Davenport (2007: 19) points out, an adjudicator 'is more likely to call for further submissions or hold a conference or make an inspection.'.

Notably, however, Davenport has proposed some significant procedural modifications with respect to the operation of the 'traditional', West Coast, process for adjudication of excontractual claims in that:

- A statutory system, similar to the current statutory payment system under the East Coast model, is prescribed for the serving of ex-contractual claims by claimants and defences by respondents prior to the lodging of a 'traditional' process adjudication application. This statutory system provides that: the claimant of an 'ex-contractual' claim must endorse its claim as being made under the Act; the respondent would have a prescribed period (Davenport uses an example of 10 business days in this respect) to provide a defence; if no defence was served within the prescribed period, a second chance to serve a defence within a further prescribed period would be permitted subsequent to a reminder notice from the claimant; and, failing the serving of the second chance defence, a claimant could initiate an adjudication by making an application to an authorised nominating authority.

- It is proposed that respondents to 'ex-contractual' claims could provide a defence, cross-claim or defence and cross-claim within the prescribed period. Further, if the defence includes a cross-claim, the claimant would have a prescribed period in which to lodge a response to the cross claim (to be called a 'rejoinder'). Davenport (2007: 18 ) states that: "This simply mirrors the usual processes of claim, defence, cross claim and rejoinder familiar to arbitrators and courts".

In Davenport's dual process, a purchaser who had obtained a determination for an 'excontractual' set off claim under the 'traditional', West Coast, process of adjudication would then be entitled to have that set off made against a progress payment amount being determined under the, East Coast, 'certification' process of adjudication.

\section{Bailey's Proposal for a Cap on Claim Amounts}

Bailey (2009: 3) advocates a cap on claim amounts under rapid mandatory adjudication schemes for payment, thereby confining the benefits of the 'short, sharp interim adjudication procedure' to participants in small business. Accordingly, Bailey (2009: 3) states:

If the intended small business focus of the reform had been more narrowly defined in the legislation and the process refined for that sector of the construction industry, then the complexities that pervade the process might not have developed as they have.

The outline conceptual framework of Bailey's proposed scheme essentially involves capping 'the value of claims and the amount of main contracts and sub-contracts which are to be 
subject to the process ... with limited or scaled or stepped processes defined' (Bailey 2009: 3).

Further, Bailey (2009: 3) proposes that:

the scheme should be limited only to claims for payment for the value of work performed. This necessarily will include work outside the contractual scope (ie variations). Time-related claims, other than those for which there is established entitlement under contractual regimes, ought be excluded.

Thus, larger and more complex disputes arising in the construction industry would not be subject to statutory rapid adjudication, instead being 'dealt with under procedures that are developed specifically for them including commercial arbitration' (Bailey 2009: 3).

\section{Proposal for a Dual Process of Adjudication based upon Size of Progress Payment Claim}

Using Davenport's concept of a dual process and Bailey's concept of claim capping, a hybrid adjudication scheme is proposed for consideration as a harmonised, unifying model.

The proposed scheme would be a dual process according to size or value of payment claim. It would employ the East Coast model process for small progress payment claims falling below a prescribed cap value, which it is suggested should initially be $\$ 25,000,{ }^{33}$ and the West Coast model process for all payment claims above the cap value. Alternatively, the proposed scheme could be a dual process according to a prescribed contract sum (eg, $\$ 100,000$ ) with the East Coast model process being used for progress payment claims on all construction contracts below the prescribed contract sum, and the West Coast model process for those above.

Payment claims which could be adjudicated under the East Coast process would be strictly limited to payment claims for construction work carried out or supply of related goods and services. Payment claims which involve disputes over what Davenport terms as 'excontractual' claims would not be permitted to be adjudicated under the capped East Coast process, but would be resolved under the West Coast process instead.

Progress payment claims which are greater in amount than the capping value for the East Coast process would be adjudicated under the West Coast process. Additionally, any payment claims, regardless of size, which involved 'ex-contractual' claims (eg, a delay damages claim within the scope of the contract, or a liquidated damages claim set off against the certified payment amount by the principal or its agent) would be adjudicated under the West Coast process.

The case for such a dual process is predicated on the notion that a 'one-size fits all' approach for the construction industry is inappropriate. Several distinct differences exist between the higher and lower ends of the hierarchical contractual chain on construction projects with respect to, inter alia: use of balanced standard forms of contract, inclusion of impartial independent certifying mechanisms for progress payment in contracts, imbalance of bargaining power between contractual parties, and commercial vulnerability to cash flow problems of relatively small amounts.

It may be argued that these differences justify the use of the more regulatory East Coast legislative approach to protect the more vulnerable smaller businesses in the lower tiers of

\footnotetext{
${ }^{33}$ Based upon the observations that the proportions of adjudication applications in Queensland are far greater for payment claims up to $\$ 25,000$ than in WA (see Table 3 above), and that adjudication fees for payment claims up to $\$ 25,000$ are significantly lower in Queensland than in WA (see Table 4 above).
}

Coggins, J (2011) 'From disparity to harmonisation of construction industry payment legislation in Australia: a proposal for a dual process of adjudication based upon size of progress payment claim', Australasian Journal of Construction Economics and Building, 11 (2) 34-59 
the hierarchical contractual chain. Further, by confining the use of the East Coast model to small claims of a simple nature, any potential negative consequences of its shortcomings with respect to procedural justice are minimised.

There are several reasons which support the consideration of this alternative dual process scheme:

- It would allow both current legislative models which are operating, and have become established, in several Australian jurisdictions to be used in a harmonised model without any significant procedural changes to either existing process. This would not only combine the strengths of both models, but may be more conducive to achieving consensus among all the Australian jurisdictions as to its adoption as the basis of a unifying model.

- It would satisfy the small business focus of parliament in the Eastern States by providing a greater level of regulatory protection to more commercially vulnerable smaller contractors for receiving straightforward progress payment in a timely and fair manner.

- The right to freedom of contract would be preserved in larger contracts, whilst not depriving larger contractors of the benefits of a still rapid and inexpensive West Coast adjudication process for progress payments - albeit one to two weeks slower than for smaller contractors under the East Coast process.

- It would allow adjudications of a 'quasi-judicial' nature for large and/or complex claims in order to determine the amount which is actually due under the contract. Large and/or complex claims would be subject to the relatively higher levels of procedural justice afforded by the West Coast process. Accordingly, there would be no possibility for a respondent to a large and/or complex claim to have their fundamental right to be heard by the adjudicator denied, and the adjudicator would be able to adopt a more evaluative approach in determining such claims.

- There have been significant uptake rates for adjudication in Queensland and NSW , particularly for smaller claims. Additionally, there is some evidence that adjudication fees for smaller payment claims (less than $\$ 25,000$ ) are several hundreds of dollars lower under the East Coast process (see section 7.1 above). The proposed dual process of adjudication would retain the East Coast process used in Queensland and NSW for smaller claims and, therefore, would be able to capitalise on these successful aspects of the East Coast process.

- There has been a high volume of litigation challenging adjudicators' determinations in NSW. Most of this litigation has concerned larger claims, and a significant proportion of such actions have been based upon the East Coast model's statutory payment system not being duly followed in some way. The volume of litigation challenging determinations of adjudicator's under the WA legislation has, to date, been relatively small. The proposed dual process of adjudication would use the West Coast process for larger claims. Additionally, the proposed dual process does not introduce a statutory system for the serving of claims, defences, counter claims and rejoinders as a preliminary to an 'ex-contractual' claim, which might potentially encourage further litigation for non-compliance with prescribed submissions procedures.

This proposed dual process concept could be further developed to allow the claimant of a progress payment claim which is less than cap value to have the option to apply for 
adjudication under the West Coast instead of the East Coast process if they so choose. ${ }^{34}$ There are two principal reasons as to why a claimant might want to do this which are both related to the preservation of the claimant's commercial relationship with the respondent:

i. If the claimant did not endorse their payment claim as being made under the Act, as is a requirement of the East Coast process, it would still be able to avail itself of the West Coast rapid adjudication process. This would circumvent the issue of contractors potentially opting not to endorse their progress payment claims for fear that such endorsement would negatively affect to some degree the working relationship between themselves and their employer. ${ }^{35}$

ii. It would provide access to the West Coast process for a claimant who believes that the West Coast process, which allows the adjudicator wider procedural flexibility, may likely result in the resolution of the progress payment dispute in a more conciliatory nature than under the East Coast process. Thus a claimant would be able to make a judgement call as to whether to sacrifice a faster-track and cheaper East Coast adjudication process for its small progress claim in order to access the potentially more conciliatory West Coast process.

This proposed dual process concept may also accommodate payment claims on construction contracts with resident owners of domestic building works ('home owners') ${ }^{36}$ as currently occurs under the West Coast model legislation, but not under the East Coast model legislation (s 7(2)(b) of the NSW Act) with the exception of the Tasmanian Act. There is a general view that the East Coast model in its current form does not provide the greater degree of protection that is required for consumers as opposed to commercial operators (Building Services Authority (Qld) 2010: 5). Additionally it is recognised by the Building Services Authority (QId) (2010: 5) that the exemption of home owner contracts:

\begin{abstract}
appears to be inconsistent with the BCIPA [the Queensland Act] objectives, to provide better outcomes for the industry, particularly since subcontractors and suppliers may make payment claims under BCIPA against a head contractor for domestic building work.
\end{abstract}

Under the proposed dual process, payment claims on construction contracts with home owners could be made under the West Coast adjudication process only. It is submitted that the West Coast process is more appropriate for home owners as it not only provides marginally longer timeframes for the serving of the prescribed documentation, but also provides more procedural justice - of which particularly pertinent aspects are the rights for home owners to also apply for adjudication of payment claims, and to have an adjudication response heard even if an earlier response to the payment claim has not been served.

\title{
Conclusion
}

Two distinct models of construction industry payment legislation have been enacted in Australia.

The East Coast model provides a highly regulatory process designed, in accordance with parliamentary intent, for the fast resolution of progress payment claims by an adjudicator

\footnotetext{
${ }^{34}$ As suggested by Robert Fenwick Elliott upon review of this paper.

${ }^{35}$ In their survey, which sought to assess the performance of the NSW Act by surveying the members of two peak trade associations operating in NSW, Brand and Uher (2010: 17) found that around half of the sampled contractor and subcontractor firms felt that endorsement of payment claims negatively affects to some degree the working relationship between the parties to a payment claim .

${ }^{36}$ As suggested by Robert Fenwick Elliott upon review of this paper.
}

Coggins, J (2011) 'From disparity to harmonisation of construction industry payment legislation in Australia: a proposal for a dual process of adjudication based upon size of progress payment claim', Australasian Journal of Construction Economics and Building, 11 (2) 34-59 
who assesses the value the construction work carried out and related good or services supplied.

The West Coast model provides a process, based upon primacy of contract, designed for the resolution of payment claim disputes ranging from those which are relatively simple to those which are complex in nature. The West Coast model, therefore, anticipates the adjudication of contractual payment claim disputes other than those involving the straightforward valuation of construction work carried out and related good or services supplied.

The scope of both the East and West Coast models is similarly wide-ranging, covering any contractor or supplier, regardless of size, who has undertaken construction work or supplied related goods and services falling within the definition of the legislation. ${ }^{37}$ In the case of the East Coast model, this is so despite its significantly limited scope with respect to types payment claims which may be subject to adjudication.

The disparity in the East Coast model between wide scope of industry participants and narrow scope of payment claim types covered has led to problems materialising in the operation of the East Coast model. These problems seem to be particularly related to its use for resolving larger progress payment claims. For example, seemingly contrary to parliamentary intent, the East Coast adjudication process has been used to determine delay damages claims by contractors and claims for set offs by principals. From a procedural justice perspective, the East Coast adjudication process is inadequate to deal with such damages claims.

Further, the numerous procedural justice shortcomings of the East Coast model make its adjudication process unsuitable for the resolution of large progress payment claims as well as more complex damages claims. It is perhaps unsurprising, therefore, that the East Coast adjudication process has generated a large volume of litigation in NSW, initiated by disgruntled respondents seeking to challenge adjudicators' determinations with respect to larger progress payment claims.

Despite its problems, however, the East Coast model appears to have been successful in terms of uptake rates in NSW and Queensland particularly for smaller claims. When confined to small, straightforward progress payment claims, it may be argued that sacrificing procedural justice may be an acceptable price to pay in order to protect vulnerable small businesses operating in the construction industry. Furthermore, whilst both East and West Coast processes provide rapid adjudication and low adjudication fees, the East Coast process appears to be significantly cheaper in terms of adjudication fees for claims less than $\$ 25,000^{38}$ and is generally around 1 to 2 weeks quicker. This may be significant in the context of a small business struggling for cash flow to survive.

The strength of the East Coast process, therefore, would appear to be in the quick resolution of small claims. Its major weakness lies in the lack of procedural justice it affords, rendering it an unsuitable form of dispute resolution for lager and/or complex claims. The shortcomings of the East Coast process, however, may be said to be where the strengths of the West Coast process lie. In affording greater respect to procedural justice and parties' freedom of contract, the West Coast model is more suited to producing adjudication outcomes which the disputing parties perceive as accurate and reliable especially where high-value and complex

\footnotetext{
${ }^{37}$ For a detailed analysis of the types of construction work covered by the various Acts, see Coggins, Fenwick Elliott and Bell (2010).

38 The analysis of data from Queensland and WA carried out in section 7.1 above would seem to suggest indicate between $\$ 450-\$ 800$ cheaper.
}

Coggins, J (2011) 'From disparity to harmonisation of construction industry payment legislation in Australia: a proposal for a dual process of adjudication based upon size of progress payment claim', Australasian Journal of Construction Economics and Building, 11 (2) 34-59 
claims are involved; a requirement which the Department of Services, Technology \& Administration (NSW) (2010: Part 1) viewed as essential in adjudication scheme performance. Further, it is suggested that adjudication outcomes which are perceived as more accurate and reliable will lead to far less challenges of adjudicators' determinations than are currently being seen in the NSW courts.

The present disparity which exists in Australian construction industry payment legislation may be turned to Australia's advantage if there can be consensus reached between the various jurisdictions as to how to combine the strengths of the East and West Coast models into a single harmonised model. It is suggested that the consideration of a dual process based upon progress payment claim size as advocated in this paper provides, at least, a starting point for agreement upon such a unified model.

\section{References}

Allred, K. G. (2005) 'Relationship Dynamics in Disputes', in The Handbook of Dispute Resolution, eds M.L. Moffitt, and R.C. Bordone, Jossey-Bass, San Francisco, 83-98

Aronson, M., Dyer, B. and Groves, M. (2004) Judicial Review of Administrative Action, $3^{\text {rd }}$ edition, Thomson Lawbook Co., Sydney, NSW

Australian Bureau of Statistics (2009) 5220.0 - Australian National Accounts: State Accounts, 2008-09 (Reissue), ABS website, viewed 20 November 2010, http://www.abs.gov.au/ausstats/abs@.nsf/Latestproducts/5220.0Main\%20Features22008-

09\%20(Reissue) ?opendocument\&tabname=Summary \&prodno=5220.0\&issue $=2008$ 09\%20(Reissue)\&num=\&view=

Australian Bureau of Statistics (2010) 3101.0 - Australian Demographic Statistics, September Quarter 2010, ABS website, viewed 7 June 2011, <http://www.abs.gov.au/ausstats/abs@.nst/mf/3101.0>

Bailey, I. (2009) 'Harmonisation or Reform of Legislation: Construction Industry and Dispute Resolution' (Paper delivered at Construction Law Seminar, Melbourne Law School, 10 November 2009)

Bell, M. and Vella, D. (2010) 'From motley patchwork to security blanket: The challenge of national uniformity in Australian 'security of payment' legislation', 84 Australian Law Journal 565

Brand, M.C. and Davenport, P. (2010) 'A proposal for a 'Dual Scheme' of statutory adjudication for the building and construction industry in Australia' Proceedings of the Royal Institution of Chartered Surveyors COBRA Conference, Paris

Brand, M.C. and Uher, T. (2010) 'Follow-up empirical study of the performance of the New South Wales construction industry security of payment legislation', International Journal of Law in the Built Environment, 2 (1), 7-25

Building and Construction Industry Payments Agency (2009) BCIPA Report Month - June 2009, Building and Construction Industry Payments Agency (Queensland Government) website, $\quad$ viewed 24 Nov 2010, <http://www.bcipa.qld.gov.au/SiteCollectionDocuments/Fact\%20Sheets/OverallStatistics June2009.pdf>

Building and Construction Industry Payments Agency (2010) BCIPA Report Month - June 2010, Building and Construction Industry Payments Agency (Queensland Government) website, $\quad$ viewed 24 Nov 2010, http://www.bcipa.qld.gov.au/SiteCollectionDocuments/Fact\%20Sheets/Overall\%20

Statistics\%202010/Overall\%20Statistics\%20-\%20June\%202010.pdf 
Building and Construction Payments Agency (2011) BCIPA Report Month - May 2011, Building and Construction Industry Payments Agency (Queensland Government) website, viewed 6 June 2011, <http://www.bcipa.qld.gov.au/SiteCollectionDocuments/

Fact\%20Sheets/Overall\%20Statistics\%202011/Overall\%20Statistics\%20-

\%20May\%202011.pdf>

Building Services Authority (QId) (2010) Building and Construction Industry Payments Act 2004 - Discussion Paper, Building Services Authority website, viewed 2 Nov 2010, $<$ http://www.bsa.qld.gov.au/SiteCollectionDocuments/BCIPA/Publications/Approved\%20Fina 1\%20Discussion\%20Paper.pdf>

Coggins, J., Fenwick Elliott, R., and Bell, M. (2010) 'Towards Harmonisation of Construction Industry Payment Legislation: A Consideration of the Success Afforded by the East and West Coast Models in Australia', Australasian Journal of Construction Economics and Building, 10 (3), 14-35

Cole, T.R.H. (2003) 'Final Report of the Royal Commission into the Building and Construction Industry', Commonwealth of Australia, February 2003

Construction Contracts Registrar (WA) (2009) 2008/09 Report of the Construction Contracts Registrar, Building Commission (WA Government) website, viewed 24 Nov 2010, $<\mathrm{http}$ //www.buildingcommission.wa.gov.au/bid/Annual_Reports_BID.aspx

Davenport, P. (2007) 'A Proposal for a Dual Process of Adjudication', Australian Construction Law Newsletter, Issue \#115, University of Technology Sydney

Davenport, P. (2010) Harmonisation of Chalk and Cheese, Society of Construction Law Australia website, viewed 18 Nov 2010, <http://www.scl.org.au/assets/Papers/HarmonisationofChalkand-Cheese.pdf>

Department of Services, Technology \& Administration (NSW) (2010) Building and Construction Industry Security of Payment Act 1999 \& Contractors Debts Act 1997 Discussion Paper, Department of Services, Technology \& Administration website, viewed 3 Nov 2010, <http://www.services.nsw.gov.au/updates/security-payment-construction-industrydiscussion-paper>

Duncan Wallace, I N (1999) 'HGCRA Adjudication: Swarms of Wannabes?', 15 (1), Construction Law Journal 20

Fenwick Elliott, R (2010) Comments on Harmonisation of Chalk and Cheese, Society of Construction Law Australia website, viewed 18 Nov 2010, $<$ http://www.scl.org.au/assets/Papers/CommentsonHarmonisationofChalk-andCheese-

RobertFenwickElliott-July2010.pdf>

Folger, R. (1977) 'Distributive and procedural justice: Combined impact of "voice" and improvement on experienced inequity', Journal of Personality and Social Psychology 35, 108-119

Greenberg, J. (1987) 'Reactions to procedural injustice in payment distributions: Do the ends justify the means', Journal of Applied Psychology, 72, 340-342

lemma, M., Building and Construction Industry Security of Payment Bill Second Reading Speech, 29 June 1999, Parliament of NSW Legislative Assembly Hansard Transcript

Kanfer, R., Sawyer, J., Earley, P. C. and Lind, E. A. (1987) 'Participation in task evaluation procedures: The effects of influential opinion expression and knowledge of evaluative criteria on attitudes and performance', Social Justice Research 1, 235-249

Latham, M. (1994) Constructing The Team - Final Report of the Government/Industry Review of Procurement and Contractual Arrangements in the UK Construction Industry, HMSO, London 
LaTour, S. (1978) 'Determinants of participant and observer satisfaction with adversary and inquisitorial modes of adjudication', Journal of Personality and Social Psychology, 36, 15311545

Lind, E. A., Kanfer, R. and Earley, P.C. (1990) 'Voice, Control, and Procedural Justice: Instrumental and Noninstrumental Concerns in Fairness Judgments', Journal of Personality and Social Psychology, 59 (5), 952-959

Lind, E. A., Kurtz, S., Musante, L., Walker, L., and Thibaut, J. W. (1980) 'Procedure and outcome effects on reactions to adjudicated resolution of conflicts of interests', Journal of Personality and Social Psychology, 39, 643-653

Lind, E. A., Lissak, R. I. and Conlon, D. E. (1983) 'Decision control and process control effects on procedural fairness judgments', Journal of Applied Social Psychology, 13, 338350

Lloyd, H (2001) 'Adjudication', International Construction Law Review, 437

McDougall, R (2006) Prohibition On Contracting Out Of The Building And Construction Industry Security Of Payment Act 1999 (NSW), NSW Supreme Court website, viewed 3 Nov $2010,<$ http://www.lawlink.nsw.gov.au/lawlink/Supreme_Court/ll_sc.nst/pages/SCO_mcdouga II270506>

MacTiernan, A.J., Construction Contract Bill Second Reading Speech, 3 March 2004, Parliament of Western Australia Legislative Assembly Hansard Transcript

Stenning \& Associates (2006) Security of Payment in the Tasmanian Building and Construction Industry, Final Report for the Minister Administering the Building Act 2000, Hobart, Tasmania

Thibaut, J., and Walker, L. (1975) Procedural Justice: A Psychological Analysis, Hillsdale, New Jersey, L. Erlbaum Associates

Tyler, T. R. (1987) 'Conditions leading to value expressive effects in judgments of procedural justice: A test of four models', Journal of Personality and Social Psychology, 52, 333-344

Tyler, T. R., Rasinski, K. and Spodick, N. (1985) 'The influence of voice on satisfaction with leaders: Exploring the meaning of process control', Journal of Personality and Social Psychology, 48, 72-81

Ury, W., Brett, J. M. and Goldberg, S.B. (1988) Getting disputes resolved: designing systems to cut the costs of conflict, San Francisco, Jossey-Bass

Zhang, T. (2009) 'Why national legislation is required for the effective operation of the security of payment scheme', 25 Building and Construction Law Journal 376 